\title{
Okul Tabanlı Afet Eğitimi
}

\author{
Bülent ÖZMEN ${ }^{1 *}$, Zeynep Didem İNCE ${ }^{2}$
}

\section{Öz}

Milli Eğitim Bakanlığı ile Japonya Uluslararası İşbirliği Ajansı arasında afet eğitimlerini yaygınlaştırmak ve okullarda afet zararlarını en aza indirme çalışmalarını etkili bir şekilde yürütebilmek için "Okul Tabanlı Afet Eğitimi Projesi" anlaşması imzalanmıştır. Marmara Bölgesinde bulunan 8 il (İstanbul, Bursa, Balıkesir, Çanakkale, Kocaeli, Sakarya, Tekirdağ ve Yalova) ile Düzce ve Bolu illerinden toplam 80 okul pilot okul olarak seçilmiştir. Proje başlaması ile birlikte oluşturulan üç çalışma grubundan birincisi projenin yürütülmesi ve yaygınlaştırılması, ikincisi Japonya ve Türkiye arasındaki müfredat karşılaşırması, eğitim materyallerinin değerlendirilmesi ve sınıf içi etkinlik planlarının hazırlanması, üçüncü ve son grup da okullardaki Afet ve Acil Durum Planlarının yeniden düzenlenmesi ve daha efektif olarak hayata geçirilmesi için çalışmalar yapmıştır. Proje kapsamında sırasıyla "Temel Afet Bilgileri", "Afet Eğitimi Etkinlikleri", "Okul Afet ve Acil Durum Yönetimi Planlama Kılavuzu", ve "Afet Eğitiminde Öğretmen Eğitimin Değerlendirilmesi" konulu dört adet kitap hazırlanmış ve başta pilot illerdeki pilot okullar olmak üzere birçok okula dağıtılmıştır. Amacımız proje kapsamında yapılan çalışmalar ve faaliyetler, hazırlanmış olan kitaplar ve elde edilen sonuçlar hakkında bilgiler vermek ve bu yönde yapılacak çalışmalara katkı sağlamaktır.

Anahtar Kelimeler: Okul, Afet, Eğitim, Acil Durum, Plan

\section{School Based Disaster Education}

\begin{abstract}
"School Based Disaster Education Project" was signed between Ministry of National Education and Japan International Cooperation Agency (JICA), to dissemination of disaster education and to effectively conduct studies for minimizing disaster damages; and total of 80 pilot schools were chosen from 8 provinces (İstanbul, Bursa, Balıkesir, Çanakkale, Kocaeli, Sakarya, Tekirdağ ve Yalova) of Marmara Region and from Düzce and Bolu. Roles of three working groups established was defined to be conducting and dissemination of the project, comparing training programs of Japan and Turkey, and redefining Disaster and Emergency Plans and applying the same more effectively, respectively for group one, group two, and group three. Within the scope of the project four books, namely "Basic Disaster Knowledge", "Disaster Education (Theory and Practice)", "Guidebook for School Disaster and Emergency Management Planning", and "Training Evaluation Method" were prepared, and these books were delivered to several schools, pilot schools in the pilot provinces being in the first place. Our objective is to give information on the studies and activities conducted, books prepared, and results obtained within the scope of the project, and to contribute to the studies to be conducted with this perspective.
\end{abstract}

Keywords: School, Disaster, Education, Emergency, Plan

\footnotetext{
${ }^{1}$ Deprem Mühendisliği Uygulama ve Araştırma Merkezi, Gazi Üniversitesi,

2 Milli Eğitim Bakanlığı Öğretmen Yetiştirme ve Geliştirme Genel Müdürlüğü

*ilgili yazar / Corresponding author: buozmen@hotmail.com

Gönderim Tarihi: 22.11.2017

Kabul Tarihi: 15.12.2017
} 


\section{GíRiş}

1 Mayıs 2003 tarihinde Bingöl'de yerel saatle 03.27 de meydana gelen 6.4 büyüklüğündeki deprem nedeniyle Çeltiksuyu köyü yakınındaki Yatılı Bölge Okulu yatakhane binası ile okul binası tamamen çökmüş ve 1 öğretmenle 84 öğrenci hayatını kaybetmiştir. Yine son yıllarda 19 Mayıs 2011 tarihinde Simav'da (Mw:5.7), 23 Ekim ve 9 Kasım 2011 tarihlerinde Van'da (Mw:7.0 ve Mw=5.6) meydana gelen depremler nedeniyle Simav'da 7, Van'da 234 okul ağır hasar görmüş ve eğitime ara verilmek zorunda kalınmıştır. Yüz yüze kaldığımız bu acı tecrübeler bize okullarımızın afete karşı daha dayanıklı ve hazır hale gelmesi gerektiğini bir kez daha göstermiştir. Bu amaçla, Milli Eğitim Bakanlığı ve Japonya Uluslararası İşbirliği Ajansı (JICA) arasında 18 Ekim 2010 tarihinde okullarda yönetici, öğretmen, öğrenci ve velilerin afet eğitimi konusunda bilinçlendirilmeleri ve afet zararlarının en aza indirilmesi amacıyla 'Okul Tabanlı Afet Eğitimi Projesi' anlaşması imzalanmıştır. Projenin süresi 3 yıldır ancak daha sonra yapılan bir anlaşma ile altı ay daha uzatılarak 2014 yılının Haziran ayı sonunda bitirilmiştir. Proje kapsamında, etkin bir okul afet ve acil durum yönetim planı kılavuzu geliştirilmesi ve örgün öğretimde okutulan ilgili ders müfredatlarının Japonya deneyimleri de göz önünde bulundurularak güncellenmesi ve geliştirilmesi, aynı paralelde ders kitap, araç, gereç ve materyallerinin hazırlanması çalışmaları yapılmıştır. Bu çalışmalar, Talim ve Terbiye Kurulu Başkanlığı, Temel Eğitim Genel Müdürlüğü, Ortaöğretim Genel Müdürlüğü ve İı Milli Eğitim Müdürlüklerinin yanı sıra, Gazi Üniversitesi, Boğaziçi Üniversitesi, Orta Doğu Teknik Üniversitesi, Kocaeli Üniversitesi, Başbakanlık Afet ve Acil Durum Başkanlığı (AFAD) ile diğer birçok resmi ve özel kurum ve kuruluş, sivil toplum kuruluşları ile birlikte koordine edilerek yürütülmüştür.

\section{OKUL TABANLI AFET EĞiTiMi}

'Okul Tabanlı Afet Eğitimi Projesi' için ilk olarak, öğretmenlerden ve akademisyenlerden oluşturulan çalışma grubunun çekirdek üyeleri, 28 Şubat - 20 Mart 2011 tarihlerinde Japonya'da, 21 gün süren 'Okullarda Afet Eğitimi ve Yönetimi' konulu eğitim almış, incelemegözlem yapmış ve müfredat karşılaştırmaları çalışmalarında bulunmuştur. Japonya'daki eğitim programı sonrasında oluşturulan 3 çalışma grubundan birincisi projenin yürütülmesi ve yaygınlaştırılması, ikincisi Japonya ve Türkiye arasındaki müfredat karşılaştırması ile eğitim materyallerinin değerlendirilmesi, üçüncü ve son grup da okullardaki Afet ve Acil Durum Yönetimi Planlarının yeniden düzenlenmesi ve daha efektif olarak yapılabilmesi/uygulanabilmesi amaçı çalışmalarına başlamıştır (Şekil 1).

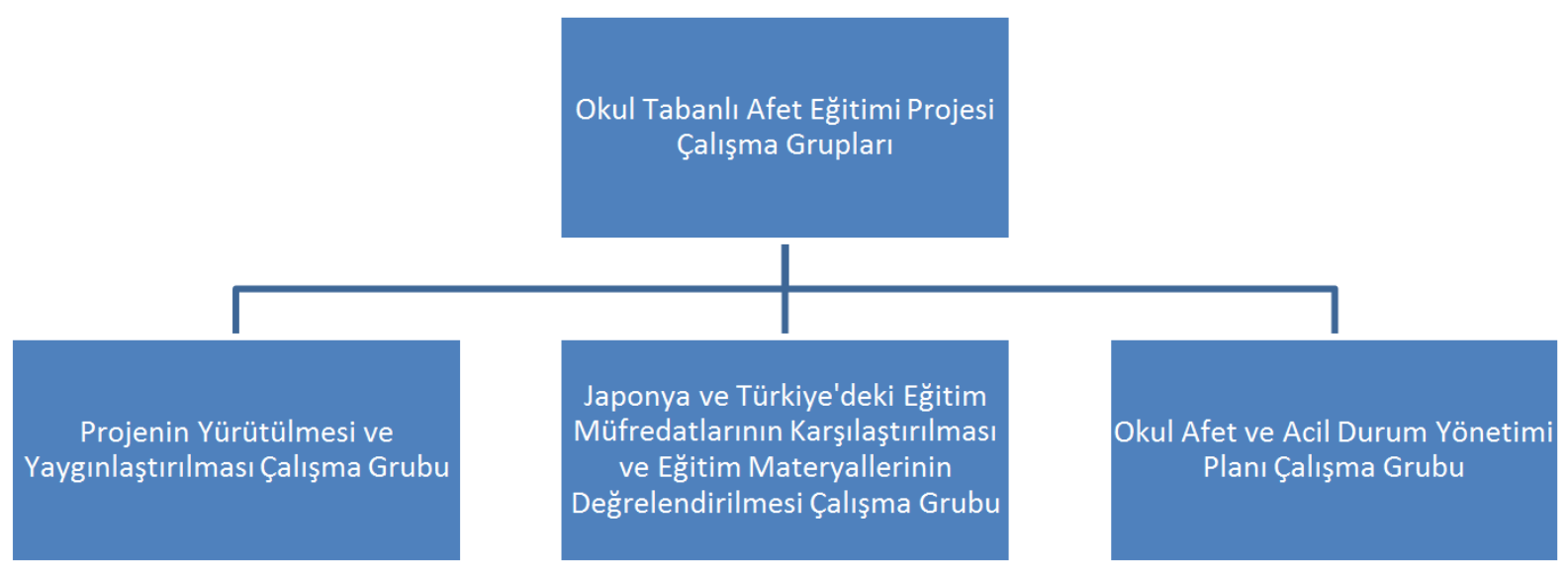

Şekil 1. Çalışma Grupları 
Her pilot il için okul sayısı ve okulların isimleri, illerin büyüklüğüne, toplam okul ve öğrenci sayılarına, farklı yapıda ve farklı ilçelerde olması gibi kriterlere göre belirlenmiştir. Böylece, pilot bölge olarak seçilen Marmara Bölgesindeki 8 il ile Düzce ve Bolu olmak üzere toplam 10 ilden 80 okulun pilot okul olarak seçilmesine ve seçilmiş olan okullara yakın ve benzer özellikler taşıyan 80 okulun da kontrol grubu okul olarak belirlenmesine karar verilmiştir (Tablo 1 ve Şekil 2). Kontrol grubu okullar, pilot olarak seçilmiş okullardaki gelişmeleri daha sağlıklı görebilmek ve projenin uygulandığı okul ile uygulanmadığı okul arasında kıyaslama yapabilmek için kullanılmıştır.

Tablo 1. Proje kapsamındaki iller ve her ilden seçilen okul sayıları

\begin{tabular}{|l|c|c|}
\hline İ Adı & Pilot Okul Sayısı & Kontrol Grubu Okul Sayısı \\
\hline İstanbul & 25 & 25 \\
\hline Tekirdağ & 4 & 4 \\
\hline Bursa & 11 & 4 \\
\hline Çanakkale & 4 & 5 \\
\hline Balıkesir & 5 & 5 \\
\hline Yalova & 5 & 8 \\
\hline Kocaeli & 8 & 6 \\
\hline Düzce & 6 & 5 \\
\hline Bolu & 5 & 7 \\
\hline Sakarya & 7 & $\mathbf{8 0}$ \\
\hline Toplam & $\mathbf{8 0}$ & \\
\hline
\end{tabular}

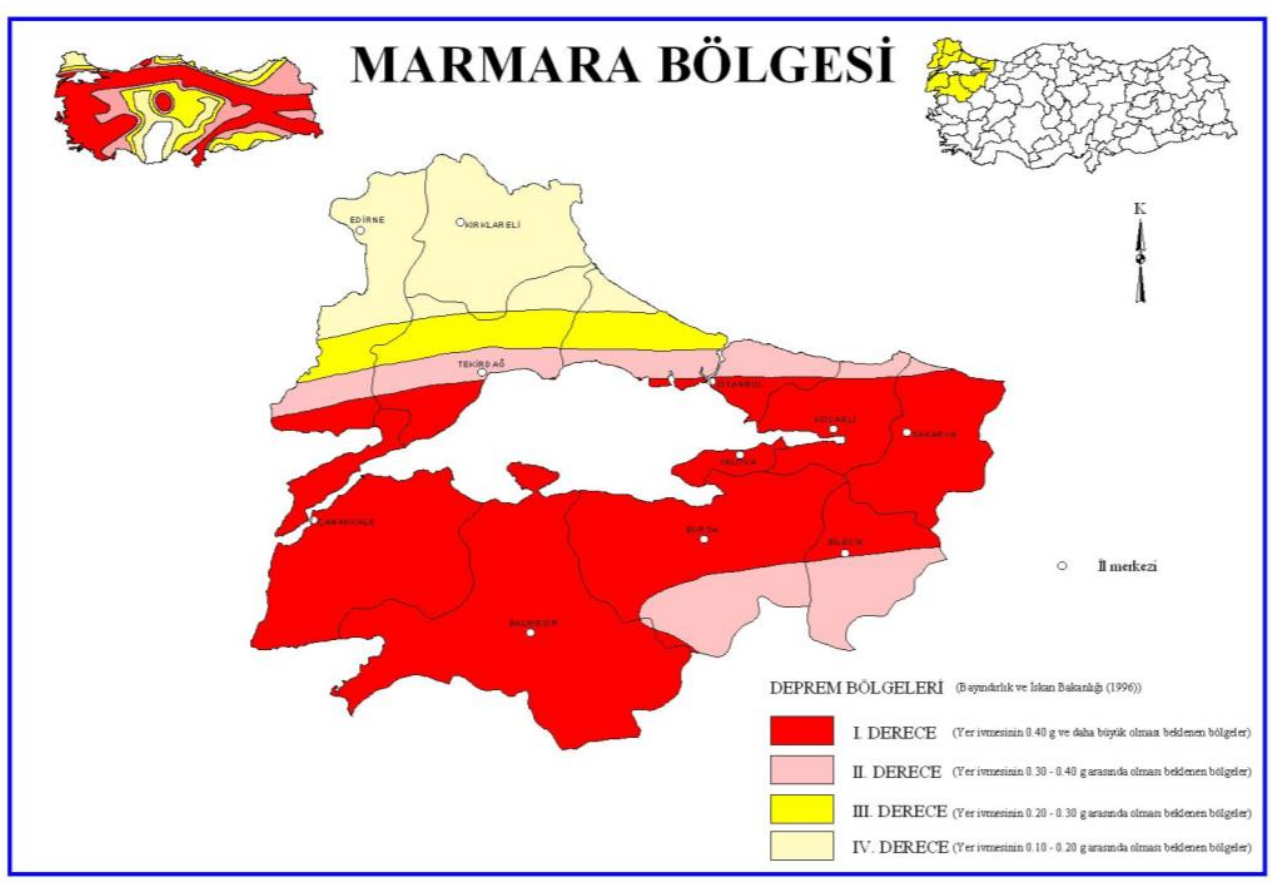

Şekil 2. Proje kapsamındaki illerin deprem bölgeleri haritasına göre durumu 
Okul Tabanlı Afet Eğitimi

School Based Disaster Education

Proje kapsamında seçilen bu 10 pilot ilden 80 pilot okul müdürü ve aynı okullardan birer müdür yardımcısı, 80 kontrol grubu okul müdürü, 10 il milli eğitim müdürü yardımcısı, 10 hizmet içi eğitimden sorumlu şube müdürü ve 10 sivil savunma uzmanının katılımları ile 26/05/2011 tarihinde İstanbul'da Proje Tanıtımı ve Bilgilendirme Toplantısı yapılmıştır. Bu toplantıda yönetici ve öğretmenlere proje ve projenin işleyişi hakkında bilgi verilmiş, projenin hedeflerine ulaşabilmek için yapılabilecekler konusunda fikir alış-verişinde bulunulmuştur.

Proje bitiminde elde edilen başarıyı değerlendirebilmek için, eğitim çalışmaları başlamadan, Eylül 2011'de belirlenen pilot ve kontrol grubu okullara web üzerinden online olarak taban araştırması anketleri düzenlenmiştir (Şekil 3). Bu anketler, yöneticiler, öğretmenler, öğrenciler ve veliler için ayrı ayrı hazırlanmıştır.

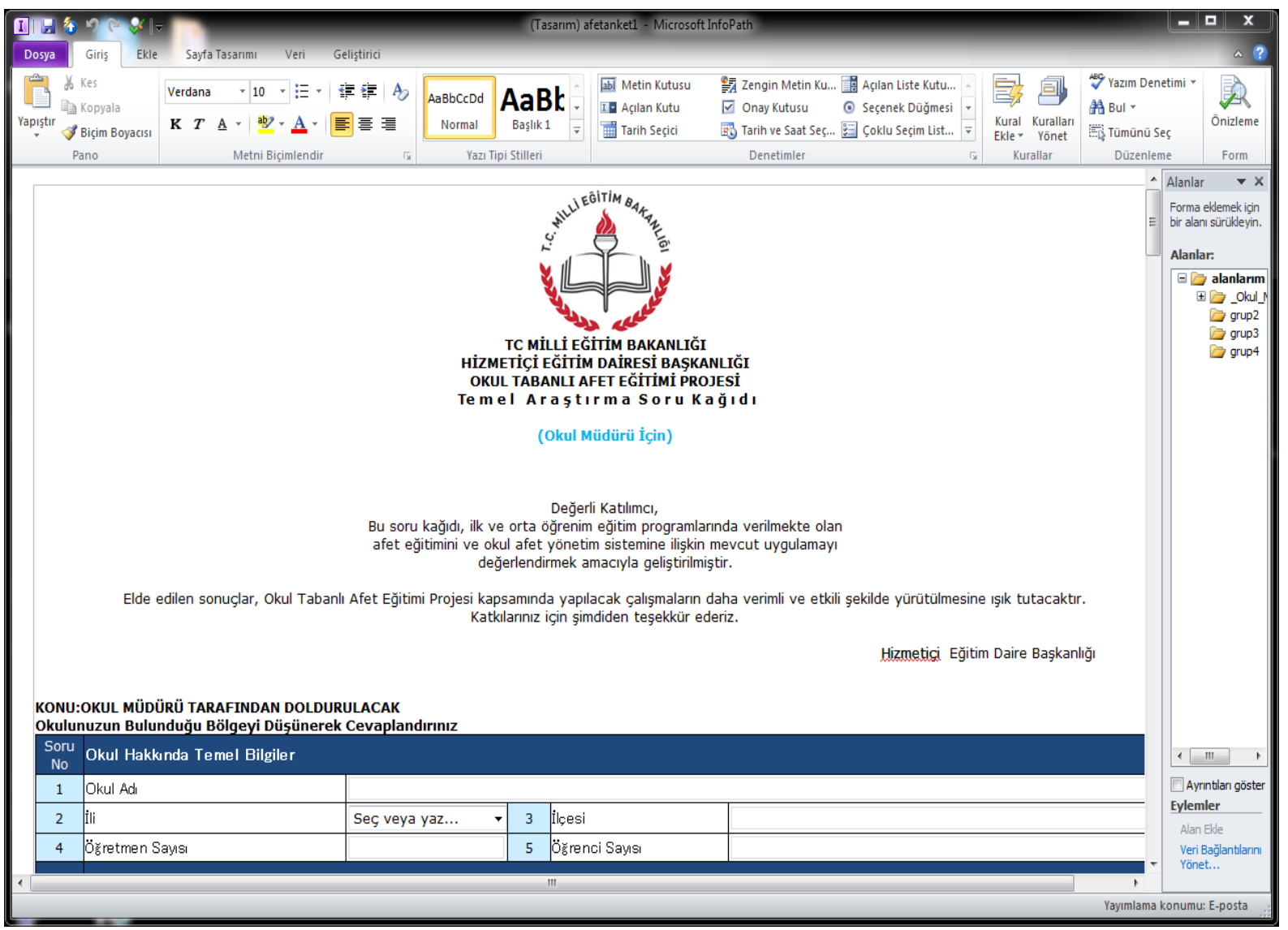

Şekil 3. Online anket örneği

Belirlenen pilot okullardan 240 öğretmen ve müdür yardımcısı, her pilot ilden 1 il eğitim denetmeni ve 1 sivil savunma uzmanı formatör olarak seçilmiş ve bu kişilere proje süresi boyunca temel afet bilinci, uygulamalı sınıf içi etkinlikler ile afet ve acil durum yönetimi planları gibi farklı konularda eğitimler verilmiştir. Her pilot ilden seçilmiş olan 1 il eğitim denetmeni ve 1 sivil savunma uzmanı eğitim planlamasını kolaylaştırma konusunda formatör öğretmenlere yardımcı olabilecekleri, bir müdür yardımcısı da okul afet ve acil durum yönetimi planlarında aktif rol ve sorumluluk alabilecekleri düşüncesiyle projeye dahil edilmiştir. Projeye gönüllü olarak katılacak olan öğretmenlerin sınıf, beden eğitimi, rehber öğretmen, sosyal bilgiler ve fen bilgisi alanlarından olmalarına dikkat edilmiştir. Eğitim alan öğretmenlerden öncelikle kendi okullarındaki öğretmen ve öğrencileri eğitmesi istenmiştir. Daha sonra bu eğitimleri alanların da farklı okullarda öğretmen ve öğrencilere eğitimler vererek projeyi yaygınlaştırmaları beklenmiştir. Projede toplam 260 formatör öğretmen görev almıştır. 
Çalışma ziyaretlerinin, anketlerin, bilgilendirme toplantılarının ve projede yer alacak öğretmenlerin seçiminin ardından üniversitelerdeki (Gazi Üniversitesi, Orta Doğu Teknik Üniversitesi, Boğaziçi Üniversitesi, Kocaeli Üniversitesi) öğretim görevlileri ve Japonya Uluslararası İşbirliği Ajansı (JICA) uzmanları ile birlikte eğitim konuları belirlenmiştir. İlk eğitim (I. Formatör Öğretmen Eğitimi) 24-30 Ekim 2011 tarihleri arasında Milli Eğitim Bakanlığının Yalova'daki Hizmetiçi Eğitim Enstitüsünde yapılmıştır. I. Formatör Öğretmen Eğitiminin sonrasında okullardaki görevlerine dönen öğretmenler, çalışmalarına başlamışlardır. Oluşturulan e-posta grubu ile yapılan çalışmalar paylaşılmış ve karşılaşılan sorunlar dile getirilmiştir. Projenin sürdürülebilir olması amacıyla e-posta grubu ve proje web sitesi üzerinden iletişim sağlanmıştır.

Formatörlerden gelen öneriler, yapılan çalışmalardan elde edilen tecrübe ve geri dönüşler doğrultusunda II. Formatör Öğretmen Eğitimi için ders planı hazırlanmıştır. Eğitimler bir önceki gibi üniversitelerin öğretim görevlileri ile birlikte gerçekleştirilmiştir. II. Formatör Öğretmen Eğitiminin yapılan I. Eğitimden en önemli farkı eğitim-öğretim teknikleri ağırıklı olması ve pratik olarak bazı uygulamaların yaptırılmış olmasıdır. Formatör öğretmenlerden ikinci eğitime gelmeden önce kendi Okul Afet ve Acil Durum Planını hazırlamak üzere bazı araştırmalar yapmaları istenmiştir. Öğretmenler ayrıca, proje kapsamında düzenlenmiş olan yarışmaya katılmak üzere eğitimde öğrendikleri gibi etkinlik planlarını ve okul projelerini hazırlama çalışmaları yapmışlardır. Formatörler ayrıca, projenin tanıtımı için birer poster örneği hazırlamış ve e-posta grubunda bu çalışmalarını paylaşmışlardır. Yarışmada başarılı bulunan öğretmenler daha detay eğitimler almak üzere Japonya'ya gönderilmiştir.

Bütün bu çalışmalarla birlikte hazırlanan ve içeriği tümüyle Milli Eğitim Bakanlığının sunucularında yer alan http://okultabanliafetegitimi.meb.gov.tr adresli proje web sitesi hazırlanmıştır (Şekil 4). Web sitesinin formatör öğretmenlerin afet eğitimini yaygınlaştırma çalışmaları için gerekli videoları ve notları indirebileceği ayrıca sorunları ve çözüm önerilerini paylaşabilecekleri bir yer olmasına çalışılmıştır. 
Okul Tabanlı Afet Eğitimi

School Based Disaster Education

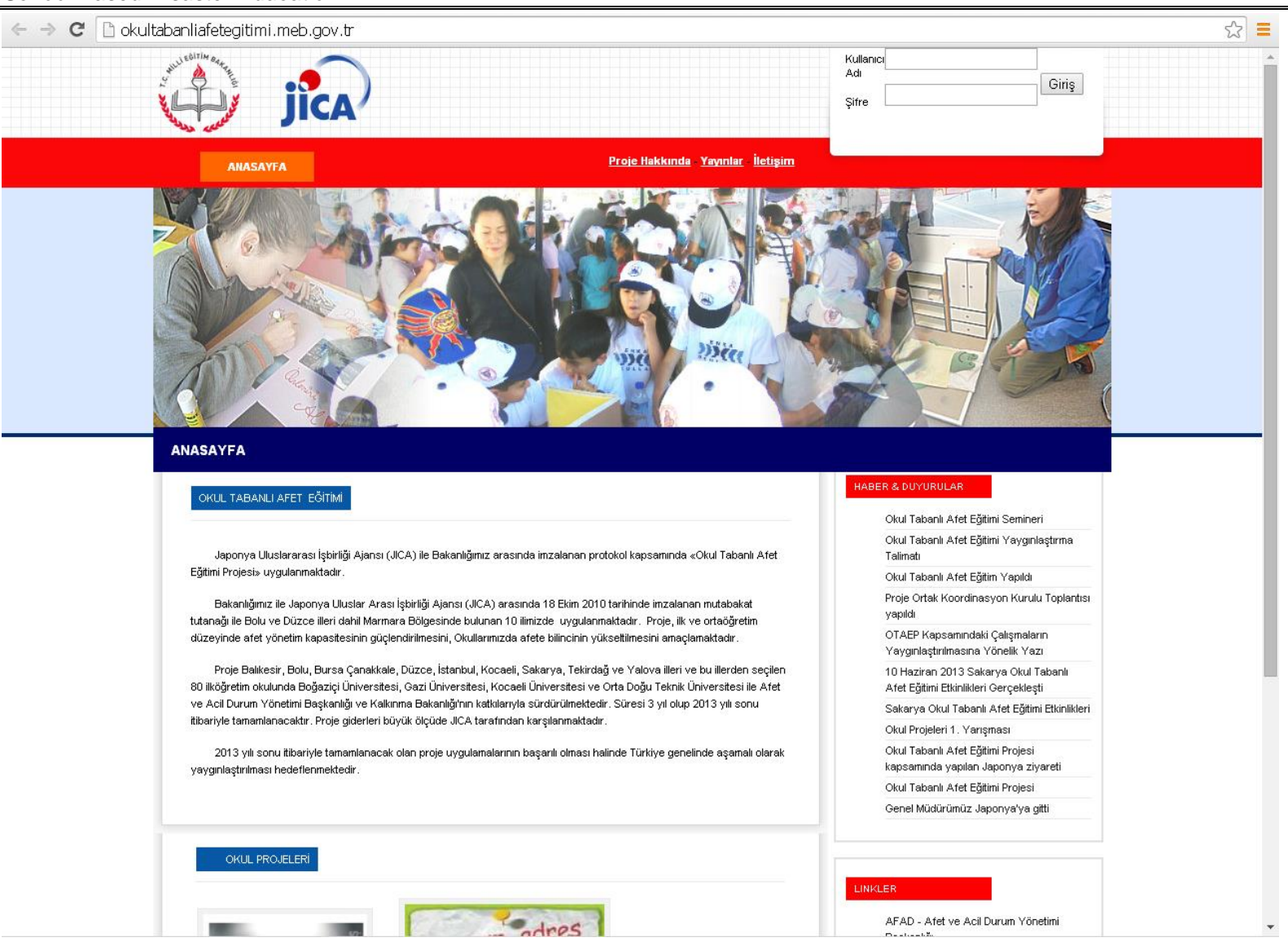

Şekil 4. Okul Tabanlı Afet Eğitimi web sayfasından bir görünüş

Okul Tabanlı Afet Eğitimi Projesi Başbakanlık Afet ve Acil Durum Yönetimi Başkanlığı tarafından uygulamaya konulan, "Ulusal Deprem Stratejisi ve Eylem Planı (2012 - 2023)"nda da yer almış ve örnek proje olarak gösterilmiştir (Şekil 5).

Ulusal Deprem Stratejisi ve Eylem Planı'nda Bakanlığımızın sorumlu kuruluş olarak gösterildiği alanlardan ikisi aşağıda belirtilmiştir

Eylem C.1.2.4. Illk ve orta öğretimde afet ve acil durum tabanlı bazı üniteler eğitim programlarına alınacaktır.

IIlk ve Ortaöğretimde okutulan bazı ders programlarında yer alan afet ve acil durumlarla ilgili konuların; günümüz şartlarına göre geliştirilmesi ve güncellenmesi sağlanacaktır. Ayrıca uzaktan eğitim bașta olmak üzere yaygın eğitim kanalıyla da bu eğitimler verilecektir.

\begin{tabular}{|c|c|c|c|}
\hline SORUMLU KURULUȘ & ÍLGILI KURULUȘLAR & $\begin{array}{c}\text { GERÇEKLEȘME } \\
\text { DÖNEMİ }\end{array}$ & $\begin{array}{c}\text { EYLEM } \\
\text { TÜRÜ }\end{array}$ \\
\hline Milli Eğitim Bakanlığı & AFAD & $2012-2013$ & Í, MD \\
\hline
\end{tabular}

Eylem C.1.2.5. Öğretmenlere afet ve acil durum ile afetlerden korunma hakkında eğitim verilecek ve bu eğitimler sürekli kılınacaktır.

Toplumun depremler ve diğer afetler konusunda bilinçenmesinde eğiticilerin konuyla ilgili eğitimleri önem tașımaktadır. Bu kapsamda ülkemizde çeșitli kurulușlar tarafından bașlatılan çalışmaların (Milli Eğitim Bakanlığı ve JICA işbirliği ile başlatılan Okul Tabanlı Afet Eğitimi Projesi gibi) geliștirilmesi gerekir.

\begin{tabular}{|c|c|c|c|}
\hline SORUMLU KURULUȘ & ÍLGILİ KURULUȘLAR & $\begin{array}{c}\text { GERÇEKLEȘME } \\
\text { DÖNEMİ }\end{array}$ & $\begin{array}{c}\text { EYLEM } \\
\text { TÜRÜ }\end{array}$ \\
\hline Milli Eğitim Bakanlığı & $\begin{array}{c}\text { AFAD, Üniversiteler, Sivil } \\
\text { Toplum Kurulușları }\end{array}$ & $2012-2023$ & $\begin{array}{c}\text { IK, } \\
\text { KG }\end{array}$ \\
\hline
\end{tabular}


Eylem B.1.2.4. Eğitim tesislerinin güçlendirme çalışmalarına öncelik verilerek devam eden çalışmalar hızlandırılacaktır.

Öncelikli olmak üzere güçlendirme çalışmaları devam eden eğitim tesislerinin tamamlanması sağlanarak ülke genelinde diğer güçlendirilmesi gereken eğitim tesislerinin çalışmalarına ivedilikle başlanacaktır.

\begin{tabular}{|c|c|c|c|}
\hline SORUMLU KURULUŞ & İLGİLİ KURULUŞLAR & $\begin{array}{c}\text { GERÇEKLEŞME } \\
\text { DÖNEMİ }\end{array}$ & $\begin{array}{l}\text { EYLEM } \\
\text { TÜRÜ }\end{array}$ \\
\hline Milli Eğitim Bakanlığı & $\begin{array}{l}\text { YÖK, İlgili Kamu Kurum ve } \\
\text { Kuruluşları, Valilikler, } \\
\text { Üniversiteler, Özel Sektör, } \\
\text { Büyükşehir Belediyeleri ve } \\
\text { Belediyeler }\end{array}$ & 2012-2017 & $\begin{array}{l}\mathrm{İK} \\
\mathrm{KG}\end{array}$ \\
\hline
\end{tabular}

Şekil 5. Ulusal Deprem Stratejisi ve Eylem Planında Milli Eğitim Bakanlığına Verilen Görevler
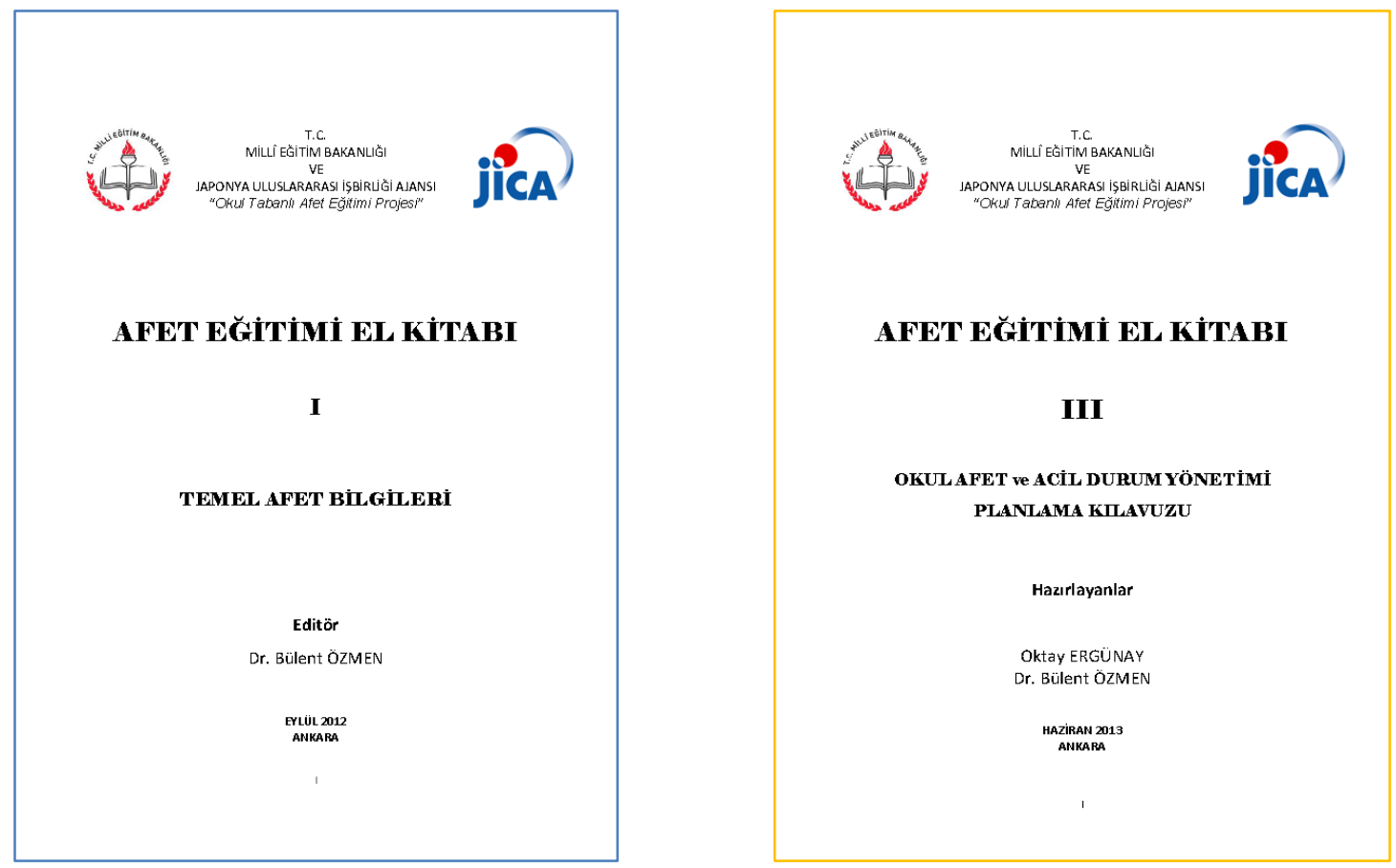


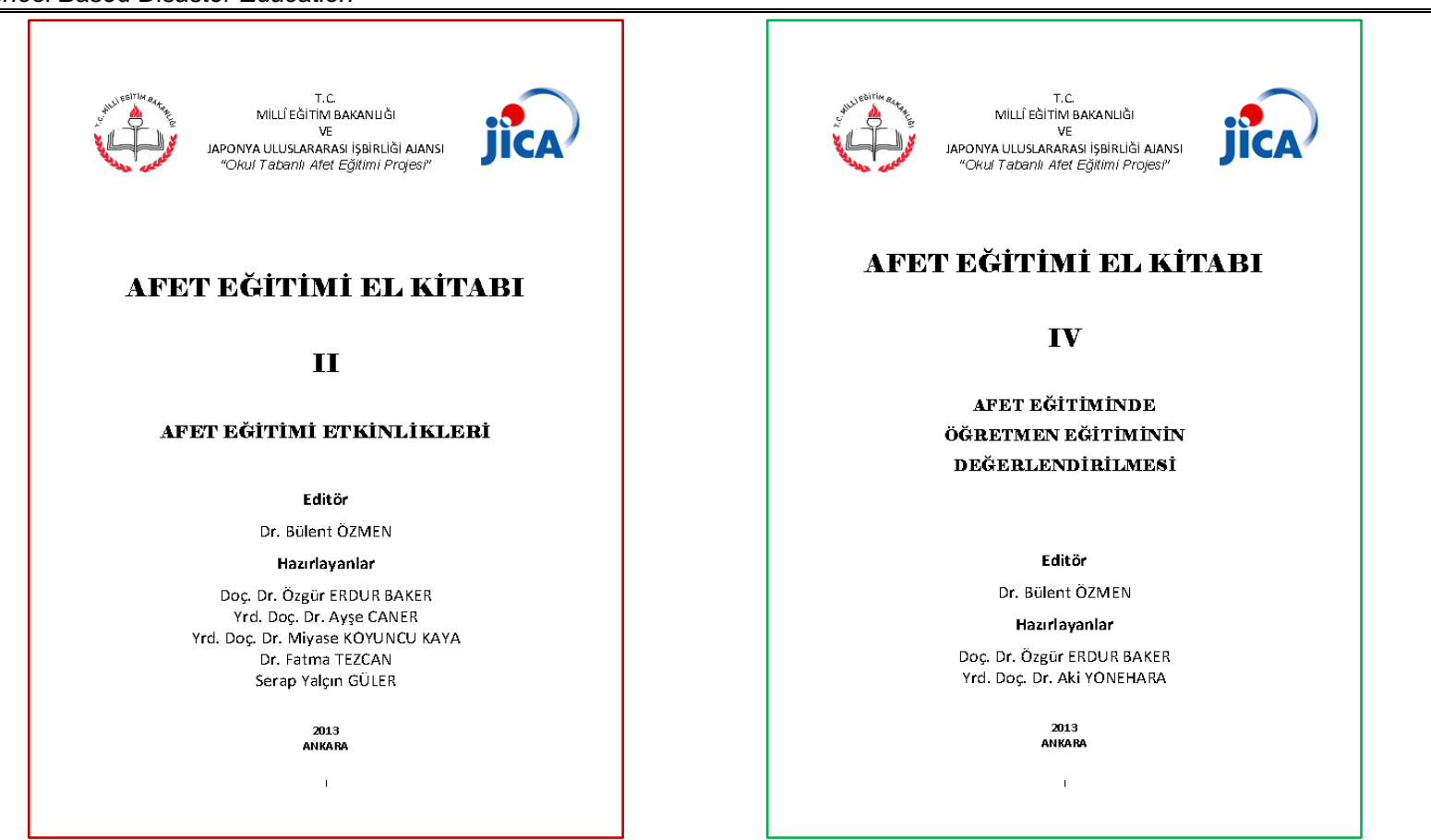

Şekil 6. Proje Kapsamında Hazırlanmış olan Kitaplar

Proje kapsamında "Temel Afet Bilgileri", "Okul Afet ve Acil Durum Yönetimi Planlama Kılavuzu", "Afet Eğitimi Etkinlikleri" ve "Afet Eğitiminde Öğretmen Eğitimin Değerlendirilmesi" konulu dört adet kitap hazırlanmış ve başta pilot illerdeki okullar olmak üzere birçok okula dağıtılmıştır (Şekil 6.). Proje kapsamında yapılmış olan faaliyetlerde özet olarak Şekil 7'de gösterilmiştir. 


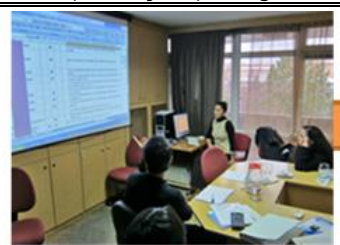

ÇG Taban Araştırması

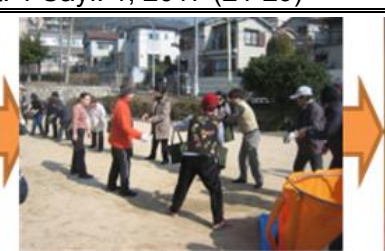

Japonya'da ÇG Eğitimi

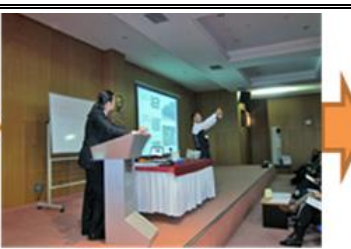

1'nci FÖ Eğitimi

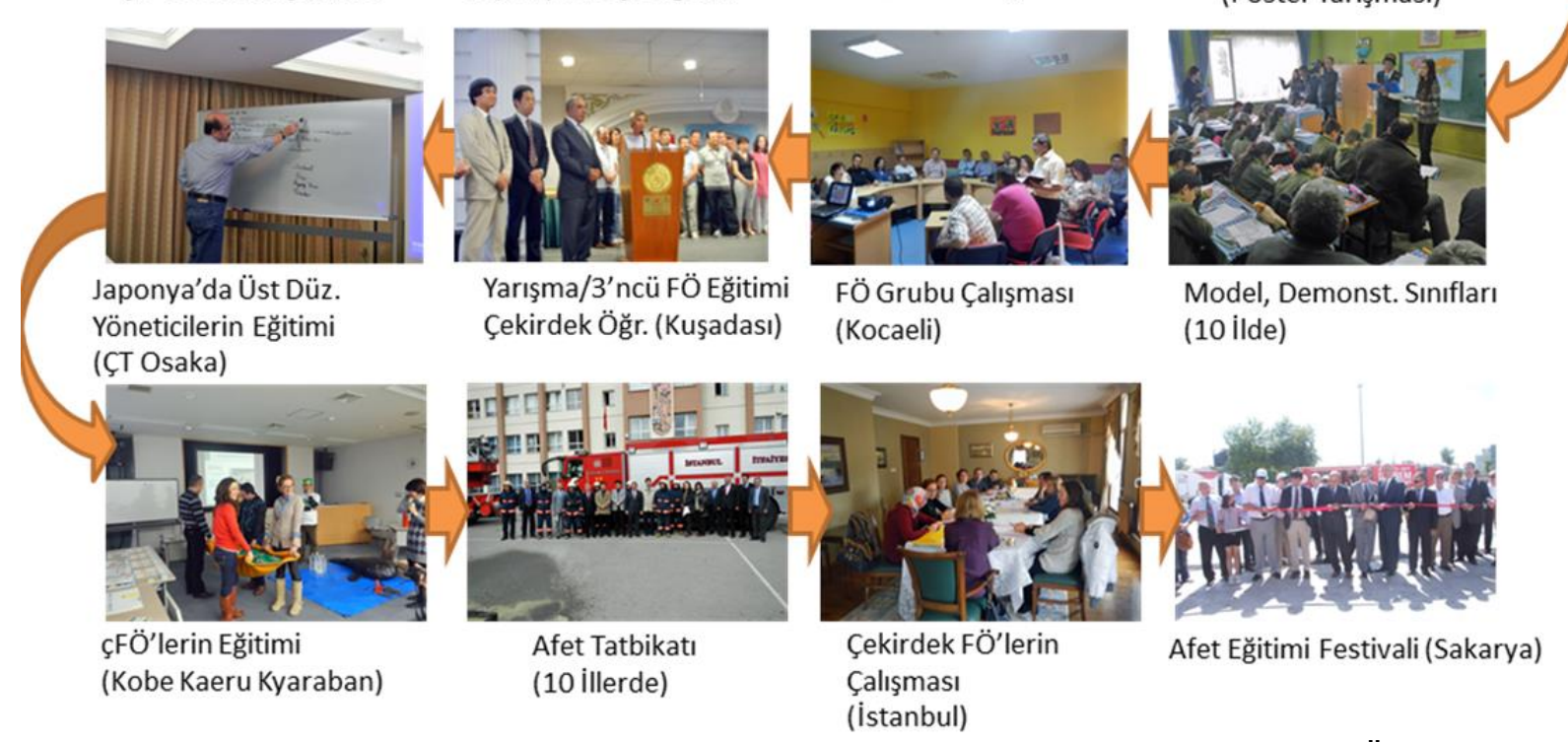

Şekil 7. Proje kapsamında yapılmış olan faaliyetler (ÇG: Çalışma grubu, FÖ: Formatör Öğretmen)

Pilot illerde sürdürülen çalışmalar büyük ölçüde tamamlandıktan sonra alınan geri bildirimler doğrultusunda projenin sürdürülebilirliği için Milli Eğitim Bakanlığınca bütün İı Müdürlüklerine neler yapmaları gerektiği konusunda bir yazı yazılmış ve çalışmaların hizmetiçi eğitimlerden sorumlu olan şube müdürlükleri aracılığı ile koordineli bir şekilde yürütülmesi istenmiştir. Hizmetiçi eğitim faaliyetlerinden sorumlu şube müdürlüğünce, il eğitim denetmeni, sivil savunma uzmanı ve eğitici ekipte yer alan formatörlerle birlikte, öğretmenlere yönelik eğitim planlarını hazırlanmıştır. Yapılan eğitim planlarının İı Milli Eğitim Müdürlüğünce onaylı bir şekilde Milli Eğitim Bakanlığına gönderilmesi gerekmektedir. Özellikle tatbikatlar başta olmak üzere eğitim süreçlerinde Başbakanlık Afet ve Acil Durum Yönetimi Başkanlığı, İl Afet ve Acil Durum Müdürlükleri, belediye ve üniversite gibi yerel birimlerin personel ve donanım imkânlarından yararlanılmaktadır. Bu bağlamda ilgili birimlerle gerekli işbirliği ve koordinasyonun sağlanması önem arz etmektedir.

Yukarıda sıralanan çalışmalar sonucunda illerde oluşturulan çekirdek ekip üyeleri Ekim 2013 de 3 günlük "Okul Tabanlı Afet Eğitimi Eğitici Eğitimi Seminerine" alınmışlardır. "Adım 0" diye adlandırılan bu eğitimden sonra afet eğitiminin yaygınlaştırıması kapsamında, çekirdek formatör öğretmenler öncelikle görevli oldukları okullarda çalışan öğretmenlere eğitim vermişlerdir. Ardından çevre okullardan başlanmak üzere il genelindeki okullarda afet eğitiminden sorumlu olacak bir müdür yardımcısı ve bir öğretmenin bu eğitimleri alması sağlanmıştır. Eğitime alınan okul sorumluları da kendi okullarındaki öğretmenleri bilgilendirmişlerdir. 
Okul Tabanlı Afet Eğitimi

\section{SONUÇLAR}

Milli Eğitim Bakanlığı ve Japonya Uluslararası İşbirliği Ajansı (JICA) arasında 18 Ekim 2010 tarihinde okullarda yönetici, öğretmen, öğrenci ve velilerin afet eğitimi konusunda bilinçlendirilmeleri ve afet zararlarının en aza indirilmesi amacıla 'Okul Tabanlı Afet Eğitimi Projesi' anlaşması imzalanmış̧ı. Projenin süresi 3 yıldır ancak daha sonra yapılan bir anlaşma ile altı ay daha uzatılarak 2014 yılının Haziran ayı sonunda bitirilmiştir. Proje kapsamında, etkin bir okul afet ve acil durum yönetim planı kılavuzu geliştirilmesi ve örgün öğretimde okutulan ilgili ders müfredatlarının Japonya deneyimleri de göz önünde bulundurularak güncellenmesi ve geliştirimesi, aynı paralelde ders kitap, araç, gereç ve materyallerinin hazırlanması çalışmaları yapılmışır.

Projenin sürdürülebilirliğini sağlayabilmek için Milli Eğitim Bakanlığı bünyesinde "Afet Eğitimi Danışma Grubu" kurulmuştur. Bu grupta ilgili Genel Müdürlüklerin Daire Başkanları bulunmaktadır. Projenin sürdürülebilirliği açısından, yapılacak eğitimlerin ve alınacak tedbirlerin bu grupta alınacak kararlar doğrultusunda sürdürülmesi planlanmaktadır.

"Okul Tabanlı Afet Eğitimi Projesi" kapsamında yapılan eğitimler ve etkinlikler sonucu öğretmenler, öğrenciler ve velilerden alınan olumlu geri bildirimler doğrultusunda eğitimin yurt geneline yayılması düşünülmektedir. Bu konuda yapılan çalışmalar devam etmektedir.

\section{KAYNAKLAR}

1. Ergünay, O., Özmen, B., 2012, Okul Afet ve Acil Durum Yönetimi Planlama Kılavuzu, Milli Eğitim Bakanlığı ve Japonya Uluslararası İşbirliği Ajansı "Okul Tabanlı Afet Eğitimi Projesi", Kitap 3, Baskı 1, 98 sayfa.

2. Özmen, B., (Editör), 2013, Afet Eğitiminde Öğretmen Eğitiminin Değerlendirilmesi, Milli Eğitim Bakanlığı, 27 sayfa, Ankara. (Hazırlayanlar: Baker, Ö.E., Yonehara, A.,)

3. Özmen, B., (Editör), 2013, Afet Eğitimi Etkinlikleri, Milli Eğitim Bakanlığı, 339 sayfa, Ankara. (Hazırlayanlar: Baker, Ö.E., Caner, A., Kaya, M.K., Tezcan, F., Güler, S.Y.,)

4. Özmen, B., (Editör), 2013, Temel Afet Bilgileri, Milli Eğitim Bakanlı̆̆ı, 320 sayfa, Ankara. 